\title{
Akibat Hukum Perkawinan yang Salah Satu Pihak Berpindah Agama Pasca Perkawinan ditinjau dari Undang-undang No.16 Tahun 2019 tentang Perubahan Atas Undang-undang No.1 Tahun 1974 tentang Perkawinan dan Kompilasi Hukum Islam
}

\author{
Salma Aisha Rahmat*, Husni Syawali \\ Prodi Ilmu Hukum, Fakultas Hukum, Universitas Islam Bandung, \\ Indonesia. \\ *aisharsalma02@gmail.com, S3husnisyawali@gmail.com

\begin{abstract}
In Islamic law the marital status is Faskh or damaged and this is also reinforced by the MUI Fatwa. Meanwhile, regarding the legal consequences of religious conversion on child custody, if it refers to Islamic law, the Muslim party has the right to take care of his child if one of the husband and wife is an infidel. However, in the Decision of Case Number 0117/Pdt.G/2016/PA.Prgi, the child who is the object of the dispute falls his custody (hadhanah) to his apostate mother. The Panel of Judges based their argument on the application of the legal principle regarding "BEST INTEREST FOR THE CHILDREN" because it was known from the facts of the trial that the child was still breastfeeding and of course the custody rights of the mother could not be released even though the mother was an apostate.
\end{abstract}

Keywords: Marriage, Apostasy, Child Custody

\begin{abstract}
Abstrak. Dalam hukum Islam status perkawinannya adalah fasakh atau rusak dan hal ini diperkuat pula dengan adanya Fatwa MUI. Sedangkan mengenai akibat hukum perpindahan agama terhadap hak asuh anak jika merujuk pada hukum Islam maka pihak yang beragama Islam yang berhak mengasuh anaknya jika ada salah satu dari pasangan suami Istri yang kafir. Tetapi dalam Putusan Perkara Nomor 0117/Pdt.G/2016/PA.Prgi anak yang menjadi obyek sengketa tersebut jatuh hak asuhnya (hadhanah) pada ibunya yang telah murtad. Majelis Hakim mendasarkan dalil mereka pada penerapan asas hukum mengenai "KEPENTINGAN YANG TERBAIK BAGI ANAK" karena diketahui dari fakta sidang bahwa Anak masih dalam kondisi menyusui dan tentunya tidak bisa dilepaskan hak asuh dari Ibunya walupun Ibu dalam kondisi murtad.
\end{abstract}

Kata Kunci: Perkawinan, Murtad, Hak Asuh Anak. 


\section{A. Pendahuluan}

Dalam kehidupan rumah tangga tidak selamanya semua hal berjalan dengan baik, karena adanya perbedaan-perbedaan yang mungkin menimbulkan perselisihan antara suami isteri yang dapat mengakibatkan hilangnya kerukunan dalam suatu rumah tangga dan jalan satu-satunya adalah dengan perceraian, apalagi jika perbedaan tersebut adalah perbedaan yang sangat mendasar seperti halnya perbedaan keyakinan.

Dalam berbagai kasus perkawinan, permasalahan pernikahan dengan perbedaan keyakinan ini tidak timbul di awal pernikahan karena masing-masing pasangan menikah secara Islam. Tetapi seiring perjalanan waktu salah satu pihak kemudian keluar dari agama Islam dengan berbagai dalih atau alasan pembenarnya.

Keluarnya seseorang dari agama Islam ini diistilahkan dengan murtad yang mana seorang tersebut berbalik kafir, membuang iman dan berganti menjadi ingkar. Dari alasan demikian sangat logis jika murtad merupakan salah satu alasan perceraian. Dengan bercerai, masing-masing pihak dapat mengamalkan ajaran agamanya dengan baik, begitupun selanjutnya mencari pasangan yang seakidah.

Sebagaimana akibat hukum dari suatu pernikahan, maka suatu perceraian juga menimbulkan akibat hukum terlebih jika dari perkawinan tersebut telah dikaruniai anak. Akibat hukum tersebut antara lain adalah permasalahan hak pemeliharaan anak atau hadhanah. Secara umum pengertian hadhanah (hak pemeliharaan anak) dalam perundang-undangan Indonesia dapat dilihat pada Pasal 1 angka 11 Undang-Undang Republik Indonesia Nomor 35 Tahun 2014 Tentang Perubahan Atas Undang-Undang Nomor 23 Tahun 2002 Tentang Perlindungan Anak, yang mana terdapat istilah "Kuasa Asuh" yaitu "kekuasaan orang tua untuk mengasuh, mendidik, memelihara, membina, melindungi, dan menumbuhkembangkan anak sesuai dengan agama yang dianutnya dan kemampuan, bakat, serta minatnya". Lebih khusus disebutkan dalam Pasal 105 Kompilasi Hukum Islam (KHI) yang menyatakan dalam hal terjadi perceraian:

1. Pemeliharaan anak yang belum mumayyiz atau belum berumur 12 tahun adalah hak ibunya.

2. Pemeliharaan anak yang sudah mumayyiz diserahkan kepada anak untuk memilih di antara ayah atau ibunya sebagai pemegang hak pemeliharaan.

Walaupun anak belum mumayyiz tetapi di putusan lain walaupun si Istri telah keluar dari agama Islam tetapi anak yang belum mumayyiz tetap harus di asuh Istri sebagai Ibunya walaupun anak sejak kecil beragama Islam. Jadi terjadi disparitas dalam putusan Hakim di Pengadilan dalam memutuskan siapa yang berhak mendapatkan hak hadhanah ketika terjadi perceraian yang mana si Istri telah keluar dari agama Islam. Hal ini sebagaimana dalam beberapa contoh putusan berikut:

1. Istri murtad tetapi hak hadhanah anak jatuh ke tangan Istri atau Ibu dari Anak yang belum Mumayyiz : PUTUSAN Nomor 0117/Pdt.G/2016/PA.Prgi

2. Istri murtad dan hak hadhanah anak jatuh ke tangan Suami atau Ayah dari Anak yang belum Mumayyiz : Putusan Nomor 1/Pdt.G/2013/PA.Blg

Dalam putusan-putusan tersebut yang menjadi obyek permasalahan adalah si Istri atau Ibu dari anak yang diperebutkan hak hadhanahnya yang mana Istri telah keluar dari agama Islam dan kemudian oleh Hakim ada yang diputuskan untuk bisa mendapatkan hak hadhanah anaknya dan ada pula yang tidak bisa mendapatkan hak hadhanah anaknya.

Berdasarkan latar belakang tersebut maka permasalahan dibantasi mengenai:

1. Bagaimanakah akibat hukum pada perkawinan yang salah satu pihaknya berpindah agama?

2. Apa yang menjadi pertimbangan hakim terhadap hak pemeliharaan anak (hadhanah) pada pasangan yang salah satunya berpindah agama berdasarkan putusan perkara nomor 0117/Pdt.G/2016/PA.Prgi?

\section{B. Landasan Teori}

Mengenai pengertian perkawinan, Lili Rasjidi memandangnya dari sudut ilmu bahasa atau semantik perkataan perkawinan berasal dari kata "kawin" yang merupakan terjemahan dari bahasa Arab nikah. Kata nikah mengandung dua pengertian, yaitu dalam dalam arti yang 
sebenarnya (haqiqat) dan dalam arti kiasan (majaaz). Dalam pengertian yang sebenarnya kata nikah itu berarti "berkumpul" sedangkan dalam arti kiasan berarti aqad atau "mengadakan perjanjian perkawinan. Berdasrkan padanan istilahnya, kata "kawin" dalam Kamus Besar Bahasa Indonesia memiliki arti 1) membentuk keluarga dengan lawan jenis; bersuami atau beristri; menikah.

Menurut Pasal 2 Kompilasi Hukum Islam, perkawinan adalah pernikahan, yaitu akad yang sangat kuat atau mitssaqan ghalidzan untuk mentaati perintah Allah dan melaksanakannya merupakan ibadah, Ungkapan akad yang sangat kuat atau mitssaqan ghalidzan merupakan penjelasan dari ungkapan "ikatan lahir batin" yang terdapat dalam rumusan UU yang mengandung arti bahwa akad perkawinan itu bukanlah semata perjanjian yang bersifat keperdataan. Sedangkan ungkapan untuk mentaati perintah Allah dan melaksanakannya merupakan ibadah, sama maknanya dengan ungkapan "berdasarkan Ketuhanan Yang Maha Esa" dalam UU Perkawinan.

Mengenai putusnya perkawinan, Kompilasi Hukum Islam (KHI) juga mengikuti alur yang digunakan oleh UU Perkawinan, walaupun pasal- pasal yang digunakan lebih banyak yang menunjukan aturan-aturan yang lebih rinci.

Putusnya hubungan perkawinan:

1. Dalam pasal 113 menyebutkan bahwa perkawinan dapat putus karena:

- Kematian

- Perceraian, dan

- Atas putusan pengadilan.

2. Putusnya perkawinan yang disebabkan karena perceraian dapat terjadi karena talak atau berdasarkan gugatan perceraian.

3. Perceraian hanya dpat dilakukan didepan sidan Pengadilan agama, setelah Pengadilan Agama tersebut berusaha dan tidak berhasil mendamaikan kedua belah pihak.

Disebutkan dalam Pasal 16 KHI menjelaskan mengenai alasan-alasan perceraian:

1. Salah satu pihak berbuat zina atau menjadi pemabuk, pemadat, penjudi dan lain sebagainya yang sulit disembuhkan;

2. Salah satu pihak meninggalkan pihak lain selama (2) tahun berturut-turut tanpa izin pihak lain dan tanpa alasan yang sah atau karena hal lain yang diluar kemampuanya;

3. Salah satu pihak melakukan kekejaeman atau penganiayaan berat yang membahayakan pihak lain;

4. Salah satu pihak mendapat cacat badan atau penyakit dengan akibat tidak dapat menjalankan kewajibanya sebagai suami/isteri;

5. Antara suami isteri terus terjadi perselisihan dan pertengkaran dan tidak ada harapan akan hidup rukun lagi dalam rumah tangga;

6. Suami melanggar taklik talak (Taklik Talak adalah janji atau pernyataan yang diucapkan suami setelah akad nikah)

7. Peralihan agama atau murtad yang menyebabkan ketidak rukunan dalam rumah tangga; Mengenai macam dan cara memutuskan hubungan perkawinan disebutkan dalam KHI antara lain :

1. Talak adalah ikrar suami dihadapan sidang Pengadilan Agama yang menjadi salah satu sebab putusnya perkawinan, dengan cara sebagaimana dimaksud dalam pasal 129, 130, dan 131.

2. Talak Raj'i adalah talak kesatu atau kedua, dalam talak ini suami berhak rujuk selama isteri dalam masa idah.

3. Talak Ba ${ }^{e}$ in Sughra adalah talak yang tidak boleh dirujuk lagi tetapi boleh akad nikah baru dengan bekas suaminya meskipun dalam iddah. (pasal 119) Talak ba'in sughra sebagaimana adalah :

- Talak yang terjadi qabla dukhul (setelah suami istri belum pernah melakukan hubungan intim).

- Talak dengan tebusan atau khuluk.

- Talak yang dijatuhkan oleh Pengadilan Agama.

4. Talak Ba'in Kubra adalah talak yang terjadi untuk ketiga kalinya. Talak jenis ini tidak 
dapat dirujuk maupun dinikahkan kembali kecuali apabila pernikahan itu dilakukan setelah bekas isteri menikah dengan orang lain dan kemudian terjadi perceraian ba'da dukhul (suami istri yang menikah sudah melakukan hubungan intim) dan habis masa iddahnya.

5. Talak sunni adalah talak yang diperbolehkan yaitu talak yang dijatuhkan terhadap isteri yang sedang suci dan tidak dicampuri dalam waktu suci tersebut.

6. Talak bid'i yaitu talak yang dilarang, yaitu talak yang dijatuhkan sewaktu istri sedang haid, atau isteri dalam keadaan suci tetapi sudah dicampuri pada waktu suci tersebut.

7. Perceraian itu terhitung pada saat perceraian itu dinyatakan didepan sidang pengadilan.

8. Khuluk harus berdasarkan atas alasan perceraian sesuai ketentuan pasal 116.

Dalam Kompilasi Hukum Islam ternyata tidak ada pembahasan Khusus mengenai Fasakh, yang mana tidak jauh beda dengan UU Perkawinan bahwa alasan Fasakh tetap sebagai alasan umum terjadinya perceraian. Berkenaan dengan cerai gugat, gugatan diajukan oleh isteri atau kuasanya kepada Pengadilan Agama yang daerah hukumnya mewilayahi daerah hukum penggugat kecuali apabila penggugat meninggalkan tempat kediaman bersama tanpa izin suami, gugatan harus ditujukan kepada pengadilan yang wilayah hukumnya mewilayahi tempat kediaman suaminya. Hak untuk memohon memutuskan perkawinan seperti ini dalam Islam disebut Khuluk.

Hak pemeliharaan anak dalam Islam disebut dengan hadhanah. Mengenai pengaturannya dalam perundang-undangan Indonesia dapat dilihat pada Pasal 1 angka 11 Undang Undang-Undang Republik Indonesia Nomor 35 Tahun 2014 Tentang Perubahan Atas Undang-Undang Nomor 23 Tahun 2002 Tentang Perlindungan Anak, yang mana terdapat istilah "Kuasa Asuh" yaitu "kekuasaan orang tua untuk mengasuh, mendidik, memelihara, membina, melindungi, dan menumbuhkembangkan anak sesuai dengan agama yang dianutnya dan kemampuan, bakat, serta minatnya". Selain itu juga dalam Pasal 1 angka 10, UU Perlindungan Anak terdapat pula istilah "Anak Asuh" yaitu :"Anak yang diasuh oleh seseorang atau lembaga, untuk diberikan bimbingan, pemeliharaan, perawatan, pendidikan, dan kesehatan, karena orang tuanya atau salah satu orang tuanya tidak mampu menjamin tumbuh kembang anak secara wajar".

Aturan yang dengan jelas dan tegas memberikan pedoman bagi hakim dalam memutus pemberian hak pemeliharaan atas anak tersebut terdapat dalam Pasal 105 Kompilasi Hukum Islam (KHI) yang menyatakan dalam hal terjadi perceraian:

a. Pemeliharaan anak yang belum mumayyiz atau belum berumur 12 tahun adalah hak ibunya.

b. Pemeliharaan anak yang sudah mumayyiz diserahkan kepada anak untuk memilih di antara ayah atau ibunya sebagai pemegang hak pemeliharaan.

c. Biaya pemeliharaan ditanggung oleh ayahnya.

Mengenai isitilah hadhanah sendiri berasal dari kata yang secara bahasa berarti mendekap atau memeluk. Secara terminologi kata hadhanah berarti al-janb yang berarti di samping atau berada di bawah ketiak atau bisa juga berarti meletakkan sesuatu dekat tulang rusuk seperti menggendong, atau meletakkan sesuatu dalam pangkuan. Maksudnya adalah merawat dan mendidik seseorang yang belum mumayyiz atau kehilangan kecerdasannya, karena mereka tidak bisa mengerjakan keperluan diri sendiri. Menurut Ahli Fiqh, hadhanah berarti memelihara anak dari segala macam bahaya yang mungkin menimpanya, menjaga kesehatan jasmani dan rohaninya, menjaga makanan dan kebersihannya, mengusahakan pendidikannya hingga ia sanggup berdiri sendiri dalam menghadapi kehidupan sebagai seorang muslim

\section{Hasil Penelitian dan Pembahasan}

Dalam UU No. 1 Tahun 1974 tidak diatur secara jelas mengenai alasan yang dapat diterima untuk melakukan perceraian karena berbeda agama. Dalam UU Perkawinan hanya menjelaskan bahwa perceraian dapat terjadi karena adanya perselisihan yang tidak ada titik temunya. Akan tetapi hal ini berbeda dengan akibat hukum perpindahan agama (murtad) terhadap status perkawinan menurut hukum Islam. Dalam hukum Islam status perkawinannya adalah fasakh atau rusak dan hal ini diperkuat pula dengan adanya Fatwa MUI. Dalam praktiknya di Indonesia, 
fasakh atau batalnya suatu perkawinan karena murtadnya salah satu pasangan terdapat perbedaan mengenai bagaimana hakim menyikapi. Sebagian Hakim menyetujui perkara fasakh diajukan ke Pengadilan melalui pembatalan perkawinan sedangkan sebagian lain menyamakan prosesnya melalui mekanisme gugatan perceraian baik itu cerai gugat oleh istri (khuluk) maupun ke dalam cerai talak. Perbedaan hakim tersebut karena dalam KHI terdapat ambiguitas dalam penafsirannya yakni di Pasal 70 KHI tidak disebutkan pernyataan mengenai suatu perkawinan itu batal apabila salah seorang suami atau istri murtad dari agama Islam. Akan tetapi tiba-tiba pada Pasal 75 KHI menyebutkan bahwa keputusan pembatalan perkawinan tidak berlaku surut terhadap perkawinan yang batal karena salah satu suami atau istri murtad. Artinya dari pasal $75 \mathrm{KHI}$ tersebut mengakui bahwa ada suatu kondisi bahwa murtad akan membatalkan perkawinan. Padahal masalah murtad tidak disebutkan sebagai syarat pembatalan perkawinan di pasal 70 KHI. Walupun demikian dengan adanya Pasal 75 KHI tersebut telah memberikan suatu landasan bagi sebagian hakim untuk melakukan pembatalan perkawinan (fasakh) karena murtad. Kemudian persoalan lain yakni di pasal $116 \mathrm{KHI}$ menyebutkan bahwa salah satu alasan perceraian adalah karena murtad. Sehingga pasal 116 tersebut merupakan landasan yuridis bagi sebagian Hakim lainnya untuk menjadikan alasan murtad sebagai landasan diajukannya gugatan perceraian baik talak maupun khuluk. Sedangkan mengenai akibat hukum perpindahan agama terhadap hak asuh anak jika merujuk pada hukum Islam maka pihak yang beragama Islam yang berhak mengasuh anaknya jika ada salah satu dari pasangan suami Istri yang kafir. Kemudian jika merujuk pada Pasal 105 Kompilasi Hukum Islam (KHI) sebagaimana telah disebutkan sebelumnya, dalam hal terjadi perceraian, pemeliharaan anak belum berumur 12 tahun atau yang disebut juga dengan mumayyiz adalah hak ibunya. Sedangkan pemeliharaan anak yang sudah mumayyiz diserahkan kepada anak untuk memilih di antara ayah atau ibunya sebagai pemegang hak pemeliharaan. Di KHI tidak disebutkan mengenai siapa yang berhak mengasuh anak jika ada yang murtad diantara kedua orang tuanya. Tetapi hal ini tentunya tidak bisa membatasi Hakim dalam memutuskan karena penggalian terhadap hukum agama, yurisprudensi dan doktrin akan menjadi acuan dalam menentukan masalah hak asuh anak dengan kondisi tersebut.

Dalam Putusan Perkara Nomor 0117/Pdt.G/2016/PA.Prgi anak yang menjadi obyek sengketa tersebut jatuh hak asuhnya (hadhanah) pada ibunya yang telah murtad. Sikap Majelis Hakim dalam putusn terkesan terkesan kontradiktif saat memilih menerapkan Pasal 105 Ayat (1) dan Pasal 156 huruf (a) KHI dengan mengenyampingkan yurisprudensi putusan Mahkamah Agung RI Nomor : 210/K/AG/1996 serta doktrin atau pendapat Ahli Sayyid Sabiq mengenai syarat pengasuhan anak muslim tidak boleh diasuh oleh pengasuh yang tidak beragama Islam. Menjadi kontradiktif karena Majelis Hakim tidak mempertimbangkan yurisprudensi dan doktrin tersebut tetapi di saat mengambil simpulan mengenai usia mumayyiz Majelis Hakim justru mengenyampingkan Pasal 105 Ayat (1) KHI mengenai batas an seorang anak mumayyiz yang berusia 12 tahun dengan memilih menentukan batasan usia 7 tahun berdasarkan doktrin atau pendapat ahli dari Diane E. Papalia dan Ruth Duskin Feldman dalam bukunya, Human Development; Perkembangan Manusia. Majelis Hakim sengaja tidak memakai penjabaran dari doktrin dan yurisprudensi dalam memutuskan siapa yang berhak dalam hak asuh anak karena Majelis Hakim mendasarkan dalil mereka pada penerapan asas hukum mengenai "KEPENTINGAN YANG TERBAIK BAGI ANAK". Diketahui dari fakta sidang bahwa Anak masih dalam kondisi menyusui dan tentunya tidak bisa dilepaskan hak asuh dari Ibunya walupun Ibu dalam kondisi murtad. Tetapi masih dengan asas "KEPENTINGAN YANG TERBAIK BAGI ANAK", maka majelis Hakim memilih menggunakan doktrin mengenai usia mumayyiz yakni 7 tahun yang menurut penulis agar akidah anak tidak mengikuti akidah Ibunya karena dikhawatirka anak tersebut disekolahkan di sekolah non muslim..

\section{Kesimpulan}

Berdasarkan pembahasan dalam penelitian ini, peneliti menyimpulkan beberapa hasil penelitian sebagai berikut:

1. Akibat hukum perpindahan agama terhadap hak asuh anak jika merujuk pada hukum Islam maka pihak yang beragama Islam yang berhak mengasuh anaknya jika ada salah satu dari pasangan suami Istri yang kafir. Kemudian jika merujuk pada Pasal 105 Kompilasi Hukum Islam (KHI) sebagaimana telah disebutkan sebelumnya, dalam hal terjadi perceraian, pemeliharaan anak belum berumur 12 tahun atau yang disebut juga dengan mumayyiz adalah hak ibunya. 
2. Dari fakta sidang bahwa Anak masih dalam kondisi menyusui dan tentunya tidak bisa dilepaskan hak asuh dari Ibunya walupun Ibu dalam kondisi murtad. Tetapi masih dengan asas "KEPENTINGAN YANG TERBAIK BAGI ANAK", maka majelis Hakim memilih menggunakan doktrin mengenai usia mumayyiz yakni 7 tahun yang menurut penulis agar akidah anak tidak mengikuti akidah Ibunya karena dikhawatirka anak tersebut disekolahkan di sekolah non muslim.

\section{Daftar Pustaka}

[1] "Pengertian Murtad", diakses melalui : http://kbbi.co.id/arti-kata/murtad, tanggal 10 Februari 2021.

[2] Mukhtie Fadjar, A. Tentang dan Sekitar Hukum Perkawinan di Indonesia, Cetakan Ke-1. Malang: Fakultas Hukum Universitas Brawijaya, 1994

[3] Lili Rasjidi, Hukum Perkawinan dan Perceraian di Malaysia dan Indonesia, PT. Remaja Rosda Karya, Bandung, 1991

[4] Departemen Pendidikan Nasional, Kamus Besar Bahasa Indonesia, Edisi Ke Tiga”, Balai Pustaka, Jakarta, 2001

[5] Amir Syarifuddin, Hukum Perkawinan Islam Di Indonesia: Antara Fiqih Munakahat Dan Undang-Undang Perkawinan, Kencana, Jakarta, 2009

[6] Mohd Idris Ramulyo, Hukum Perkawinan Islam Suatu Analisis Dari Undang-Undang No 1 Tahun 1974 dan Kompilasi Hukum Islam, Bumi Aksara, Jakarta, 1996

[7] Amiur Nuruddin dan Azhari Akmal Tarigan, Hukum Perdata Islam di Indonesia, Kencana, Jakarta, 2004.

[8] Munawwir, Kamus Arab-Indonesia, Pustaka Progressif, Surabaya, 2007.

[9] Andi Syamsyu Alam, Hukum Pengangkatan Anak, Kencana, Jakarta, 2008

[10] Kamal Muchtar, Asas-asas Hukum Islam tentang Perkawinan, Bulan Bintang, Jakarta 